\title{
Effects of suppressing plasma FSH on ovarian follicular dominance in cattle
}

\author{
A. M. Turzillo* and J. E. Fortune $\dagger$ \\ Department and Section of Physiology, College of Veterinary Medicine, Cornell University, Ithaca, \\ NY 14853, USA
}

\begin{abstract}
The importance of FSH during development of the dominant follicle of the first wave of follicular growth in cattle was assessed by injecting heifers twice daily with $20 \mathrm{ml}$ saline $(n=$ 6) or $20 \mathrm{ml}$ charcoal-extracted bovine follicular fluid (bFF; $n=10$ ), containing inhibin, on days 6 and 7 of the oestrous cycle. All animals received a luteolytic dose of PGF $2 \alpha$ on day 8 . The interval to oestrus after $\mathrm{PGF}_{2 \alpha}$ in controls was $2.6 \pm 0.2$ days. Five of ten bFF-treated heifers exhibited oestrus at the same time as controls ( $2.7 \pm 0.1$ days), whereas time to oestrus in the remaining five bFF-treated heifers was significantly longer ( $6.8 \pm 0.6$ days; $P<0.05)$. Treatment with bFF suppressed plasma FSH during the $48 \mathrm{~h}$ injection period $(P<0.05)$. Concentrations of FSH were not different in bFF-treated animals that did not display delayed oestrus compared with those in animals that exhibited delayed oestrus. In controls, the dominant follicle of the first wave continued growing during treatment and ovulated after injection of $\mathrm{PGF}_{2 \alpha}$. In all ten bFF-treated animals, growth of the dominant follicle of the first wave was arrested during the treatment period. In bFF-treated animals that did not exhibit delayed oestrus, the dominant follicle resumed growth after luteolysis and ovulated. In bFF-treated animals that displayed delayed oestrus, the dominant follicle regressed after luteolysis and the ovulatory follicle was selected from a newly recruited (second) wave of follicular growth. Maximal increases in concentrations of oestradiol in plasma reflected preovulatory follicular development and occurred at the time of oestrus, 2 or 3 days after PGF $_{2 \alpha}$ injection in saline- and bFF-treated heifers that did not display delayed oestrus, and 5-8 days after $\mathrm{PGF}_{2 \alpha}$ in animals in which oestrus was delayed. No differences in concentrations of plasma $\mathrm{LH}$ or progesterone were detected between groups. Arrested growth of the dominant follicle of the first wave, associated with suppressed concentrations of basal FSH, suggests an important role for FSH during ovarian follicular dominance in cattle.
\end{abstract}

\section{Introduction}

The use of ultrasound imaging has clearly elucidated the pattern of ovarian follicular growth in cattle. Follicular development is characterized by the recruitment of two or three successive cohorts of follicles during each oestrous cycle. From each cohort, a single follicle is selected to develop into a large dominant follicle (Savio et al., 1988; Sirois and Fortune, 1988; Knopf et al., 1989). Although experiments with sheep have provided evidence that basal levels of gonadotrophins are required for follicular recruitment (Dufour et al., 1979; McNeilly et al., 1986; Driancourt et al., 1987), the importance of gonadotrophin support during later stages of follicular maturation has not been addressed definitively.

One hypothesis about the mechanism by which follicular dominance is achieved suggests that in the presence of basal gonadotrophin concentrations, a single follicle continues to

${ }^{*}$ Current address: Dept of Physiology, Colorado State University, Fort Collins, CO 80523, USA.

$\uparrow$ Reprint requests.

Received 28 May 1992. grow and mature because it acquires increased sensitivity to FSH, while further development of other follicles in the same cohort with less sensitivity to FSH is inhibited (Baird, 1987). Receptors for FSH are present on bovine granulosa cells of oestrogen-active follicles on day 3 of the oestrous cycle, and there are more LH receptors on theca and granulosa cells of oestrogen-active follicles on day 7 than on day 3 (Ireland and Roche, 1983). The dominant follicle of the first wave in cattle may therefore acquire increased responsiveness to $\mathrm{LH}$ in response to FSH and thus produce significant quantities of oestradiol (Richards, 1980; Hillier, 1991). There is evidence that in bovine preovulatory follicles, oestradiol exerts positive feedback on its own production (Fortune and Quirk, 1988). Increasing local concentrations of oestradiol within the dominant follicle may in turn further sensitize granulosa cells to FSH, providing a mechanism for continued development in the presence of basal concentrations of FSH (Zeleznik and Hillier, 1984).

The objective of the present study was to assess the importance of FSH during development of the dominant follicle of the first wave of follicular growth during the bovine oestrous cycle. Endogenous secretion of FSH was suppressed using charcoal- 
extracted bovine follicular fluid, a rich source of the glycoprotein inhibin (Robertson et al., 1985), which selectively inhibits secretion of FSH in intact heifers (Quirk and Fortune, 1986; Lussier and Carruthers, 1989; Turzillo and Fortune, 1990). After exposure of dominant follicles to decreased concentrations of basal FSH, luteolysis was induced and the ovulatory capacity of the follicles was assessed and compared with that of controls. We hypothesized that the developing dominant follicle is sensitive to endogenous FSH concentrations, and that depriving this follicle of basal FSH would compromise its ability to continue growing and complete preovulatory maturation. A brief report of the results has appeared in abstract form (Turzillo and Fortune, 1991).

\section{Materials and Methods}

\section{Animals}

Mature Holstein heifers with normal oestrous cycles were used during the months of January, April and December. Animals were housed in a stanchion barn and fed corn silage and hay with mineral supplement. Oestrous cycles were synchronized by a single injection of $25 \mathrm{mg}$ PGF $_{2 \alpha}$ (Lutalyse: Upjohn Co., Kalamazoo, MI) administered i.m. between days 6 and 15 of the cycle. After prostaglandin-induced oestrus, all heifers completed one cycle of normal duration before undergoing further treatment.

\section{Experimental design}

Ten heifers were treated at intervals of $12 \mathrm{~h}$ with $20 \mathrm{ml}$ charcoal-extracted bovine follicular fluid (bFF) i.v. on days 6 and 7 of the oestrous cycle and six control heifers were treated with $20 \mathrm{ml} 0.9 \%$ saline following the same schedule. Collection and preparation of the pool of bFF used in these experiments were as described by Turzillo and Fortune (1990). Briefly, bFF was collected at an abattoir and extracted with charcoal to remove steroids. Concentrations of oestradiol and progesterone in the bFF pool were reduced from 63.7 to $0.03 \mathrm{ng} \mathrm{ml}^{-1}$ and from 66.3 to $0.65 \mathrm{ng} \mathrm{ml}^{-1}$, respectively. In a previous study we showed the effectiveness of this pool of bFF in suppressing plasma FSH: injection of $10 \mathrm{ml}$ twice daily completely suppressed the secondary surge of FSH (Turzillo and Fortune, 1990).

On the morning of day 8 ( $12 \mathrm{~h}$ after the final bFF or saline injection) all animals received $25 \mathrm{mg} \mathrm{PGF}_{2 \mathrm{a}}$ i.m. Heifers were observed for oestrous behaviour every $12 \mathrm{~h}$ beginning $48 \mathrm{~h}$ after PGF $_{2 \alpha}$ injection. Blood samples were collected at $4 \mathrm{~h}$ intervals from jugular venous catheters (Intracath; $16 \mathrm{~g} \times 12$ in, Deseret Medical Inc., Sandy, UT). Sampling began on day 5 and was continued until $16 \mathrm{~h}$ after the first observation of oestrus. Catheters were filled with heparin-saline $\left(200 \mathrm{iu} \mathrm{ml}^{-1}\right)$ between sampling times. Blood was centrifuged $(2000 \mathrm{~g})$ immediately and plasma was harvested and stored at $-20^{\circ} \mathrm{C}$ for later measurement of $\mathrm{FSH}, \mathrm{LH}$, progesterone and oestradiol by radioimmunoassay.

Ovaries were examined daily using a real-time B-mode linear array ultrasound scanner equipped with a $7.5 \mathrm{MHz}$ probe
(Technicare 210DX; Corometrics, North Branford, CT). This procedure has been described in detail by Quirk et al. (1986). Heifers were not anaesthetized during ultrasonography. Examinations were recorded on videotape (Ampex Videocassette, Ampex Corp., Redwood City, CA) and subsequently reviewed on a video monitor (Panasonic NV8950; Matsushita Electric Corp., Secaucus, NJ). Patterns of growth and regression of all follicles with antral diameters $\geq 5 \mathrm{~mm}$ were recorded. Ultrasonography was started on day 0 or 1 of the treatment cycle and continued until ovulation occurred, following treatment with $\mathrm{PGF}_{2 \alpha}$ on day 8 and subsequent oestrus.

\section{Radioimmunoassays}

FSH was measured in plasma samples with a homologous radioimmunoassay (Bolt and Rollins, 1983) using USDAbFSH-B-1 as standard, USDA-FSH-BP3 for radioiodination and antiserum to the bovine FSH- $\beta$ subunit (USDA-5-0122) as previously reported (Turzillo and Fortune, 1990). Sensitivity of this radioimmunoassay was $0.93 \mathrm{ng}$ per assay tube, with an intra-assay CV of $9.5 \%$ and an interassay CV of $15.3 \%$.

Plasma concentrations of $\mathrm{LH}$ were measured by heterologous radioimmunoassay (Niswender, 1969) using NIH LH-B9 as standard, ovine LH (LER-1056-C2) for radioiodination and antiovine LH (CSU-204) as first antibody. Sensitivity of this assay was $0.07 \mathrm{ng}$ per assay tube. The intra-assay $\mathrm{CV}$ was $9.4 \%$ and the interassay $\mathrm{CV}$ was $15.1 \%$.

Progesterone concentration was determined in plasma samples extracted with petroleum ether (Beal et al., 1980). Recovery of tritiated progesterone added to bovine plasma was $75.5 \pm 1.9 \%$. Solvent blanks were negligible and values were not corrected for recovery. Sensitivity of this radioimmunoassay was $12.5 \mathrm{pg}$ per assay tube $\left(0.125 \mathrm{ng} \mathrm{ml}^{-1}\right.$ plasma); intra- and interassay CVs were $9.4 \%$ and $9.6 \%$, respectively.

Oestradiol was measured using a modification of a commercially available radioimmunoassay (Second Antibody Estradiol; Diagnostic Products Corp., Los Angeles, CA), validated in our laboratory for measuring oestradiol in bovine plasma extracted with diethyl ether (Turzillo and Fortune, 1990). Recovery of iodinated oestradiol was $88.1 \pm 1.0 \%$, and solvent blanks were negligible. Values were not corrected for recovery. Oestradiol concentration in plasma of an ovariectomized heifer (plasma blank) was $0.08 \mathrm{pg}$ per assay tube $\left(0.8 \mathrm{pg} \mathrm{ml}^{-1}\right.$ plasma). Sensitivity of this RIA was $0.07 \mathrm{pg}$ per assay tube $\left(0.7 \mathrm{pg} \mathrm{ml}^{-1}\right.$ plasma), with an intra-assay $\mathrm{CV}$ of $14.9 \%$ and an interassay $\mathrm{CV}$ of $18.9 \%$.

\section{Statistical analyses}

Differences in endocrine parameters between control and bFF-treated heifers were assessed by split-plot analysis of variance for repeated measures (SAS, 1985). Student's $t$ test was used for comparison of time to oestrus in control versus bFFtreated heifers. For comparison of more than two groups, oneway analysis of variance followed by Scheffe's procedure for separation of means (Lentner and Bishop, 1986) was used to assess differences in time to oestrus following $\mathrm{PGF}_{2 \alpha}$ and parameters of ovarian follicular growth and regression. All values are presented as means \pm SEM. 
Table 1. Time to oestrus after injection of heifers with saline or bovine follicular fluid (bFF) twice daily on days 6 and 7 and with $\mathrm{PGF}_{2 \alpha}$ on day 8 of the oestrous cycle

\begin{tabular}{lll}
\hline Treatment & $\begin{array}{c}\text { Time to oestrus } \\
\text { (days) }\end{array}$ & $\begin{array}{c}\text { Range } \\
\text { (days) }\end{array}$ \\
\hline Controls $(n=6)$ & $2.6 \pm 0.2$ & $2.0-3.5$ \\
bFF - all heifers $(n=10)$ & $4.8 \pm 0.8^{*}$ & $2.5-8.5$ \\
bFF - oestrus not delayed $(n=5)$ & $2.7 \pm 0.1$ & $2.5-3.0$ \\
bFF - oestrus delayed $(n=5)$ & $6.8 \pm 0.6^{*}$ & $5.0-8.5$ \\
\hline
\end{tabular}

Values are means \pm SEM

*Significantly different from controls $(P<0.05)$.

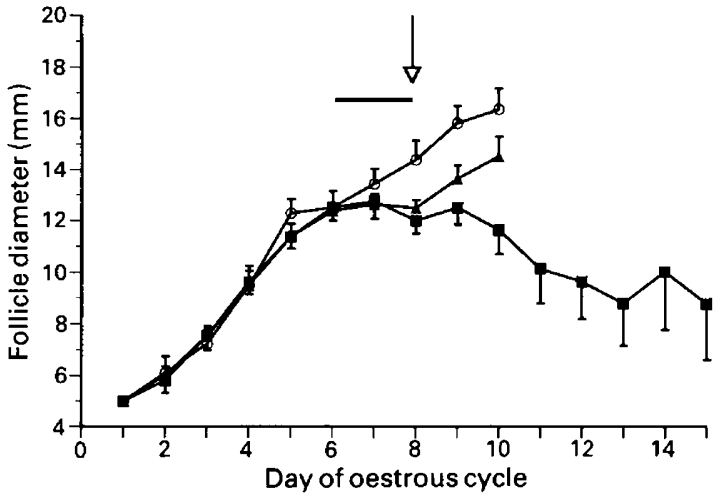

Fig. 1. Mean diameters of dominant follicles of the first wave of follicular development in heifers injected i.v. with saline $(n=6 ;-\mathrm{O}-)$ or bovine follicular fluid (bFF) $(n=10)$ twice daily on days 6 and 7 of the oestrous cycle (as indicated by the horizontal bar). Injection of PGF on day 8 is indicated by the arrow. Diameters of dominant follicles in animals that exhibited oestrus at the same time as controls (bFF not delayed; $n=5$; $-\mathbf{\Delta}-$ ) are plotted separately from those in animals that took significantly longer than controls to exhibit oestrus (bFF - delayed; $n=5 ;-\mathbf{\square}-$ ).

\section{Results}

\section{Effects of bFF on time to oestrus}

Saline-treated heifers were observed in oestrus 2 or 3 days following injection of $\mathrm{PGF}_{2 \alpha}$ on day 8 (Table 1); time to oestrus after $\mathrm{PGF}_{2 \alpha}$ was significantly longer in bFF-treated heifers $(P<0.05)$. Noting the large variability in time to oestrus in animals injected with $\mathrm{bFF}$, we observed two subgroups within the bFF group; five of ten bFF-treated heifers exhibited oestrus at times similar to those in controls, while time to oestrus was significantly longer, compared with controls, in the remaining five bFF-treated animals $(P<0.05)$.

\section{Effects of $b F F$ on follicular dynamics}

In response to saline treatment, dominant follicles continued to grow and eventually became ovulatory follicles in all six control animals (Fig. 1). Treatment with bFF differentially affected dominant follicular development. In bFF-treated heifers in which the time to oestrus following $\mathrm{PGF}_{2 a}$ injection was not delayed, the dominant follicle of the first wave also became the ovulatory follicle, although its growth was temporarily attenuated during treatment $(P<0.05$; Fig. 1). Heifers with delayed oestrus did not ovulate the dominant follicle present at the start of bFF injections; no perceptible growth of this follicle occurred during treatment, and it eventually regressed. A second wave of follicular growth appeared in these animals on day 10, and in each case a single follicle was selected to achieve dominance and ovulate (Fig. 2e, f).

No differences were detected between saline- and bFFtreated heifers (regardless of time to oestrus) with respect to day of appearance of the dominant follicle, its growth rate prior to treatment, or its size at the start of treatment (Table 2). As a result of its cessation of growth in response to bFF treatment, the first dominant follicle in bFF-treated animals showing delayed oestrus failed to grow as large as dominant follicles in controls $(P<0.05)$ and reached maximal size earlier than dominant follicles in either control heifers or bFF-treated heifers with no delay to oestrus $(P<0.05)$. Longer persistence (defined as the number of days a follicle was visible with antral diameter $\geq 5 \mathrm{~mm}$ ) of dominant follicles in bFF-treated animals showing delayed oestrus compared with controls reflects the regression phase of these non-ovulatory follicles. Growth rates of dominant follicles were not different before the start of injections. During treatment, growth of the dominant follicle continued in controls but effectively ceased in bFF-treated heifers $(P<0.05)$. Growth rates of dominant follicles after treatment did not differ between controls and bFF-treated heifers not displaying delayed oestrus.

Regression of the first dominant follicle in bFF-treated animals displaying delayed oestrus was accompanied by recruitment of a second wave of follicular development. The dominant follicle of this wave first appeared on average on day $10.4 \pm$ 0.3 , grew $2.1 \pm 0.2 \mathrm{~mm} \mathrm{day}^{-1}$, reached a maximal diameter of $14.3 \pm 1.0 \mathrm{~mm}$ on day $14.8 \pm 0.7$, and persisted for $5.4 \pm 0.8$ days.

The mean number of follicles with antral diameters $\geq 5 \mathrm{~mm}$ comprising the first wave of follicular development did not differ among controls $(6.7 \pm 1.3$ follicles), bFF-treated heifers without delayed oestrus $(7.4 \pm 1.2$ follicles), and bFF-treated heifers displaying delayed oestrus $(4.2 \pm 0.6$ follicles $)$. The mean number of follicles in the second wave of follicular development in heifers with delayed oestrus was $6.6 \pm 1.2$.

\section{Effects of bFF on endocrine parameters}

Mean concentrations of FSH were not different between groups during the $24 \mathrm{~h}$ prior to treatment, although a time $x$ treatment interaction was detected during this time $(P<0.05)$. Mean concentrations of FSH in plasma were lower in bFFtreated heifers than in controls during the treatment period (i.e. for $48 \mathrm{~h}$ between the first injection on day 6 and the time of $\mathrm{PGF}_{2 \alpha}$ injection on day 8; $P<0.05$, Fig. 3). During the $48 \mathrm{~h}$ after the end of treatment, FSH concentrations increased but were not significantly higher than values in controls. A time $x$ treatment interaction was detected during this period $(P<0.001)$. When plasma concentrations of FSH in bFF-treated heifers that did not display delayed oestrus were compared with 

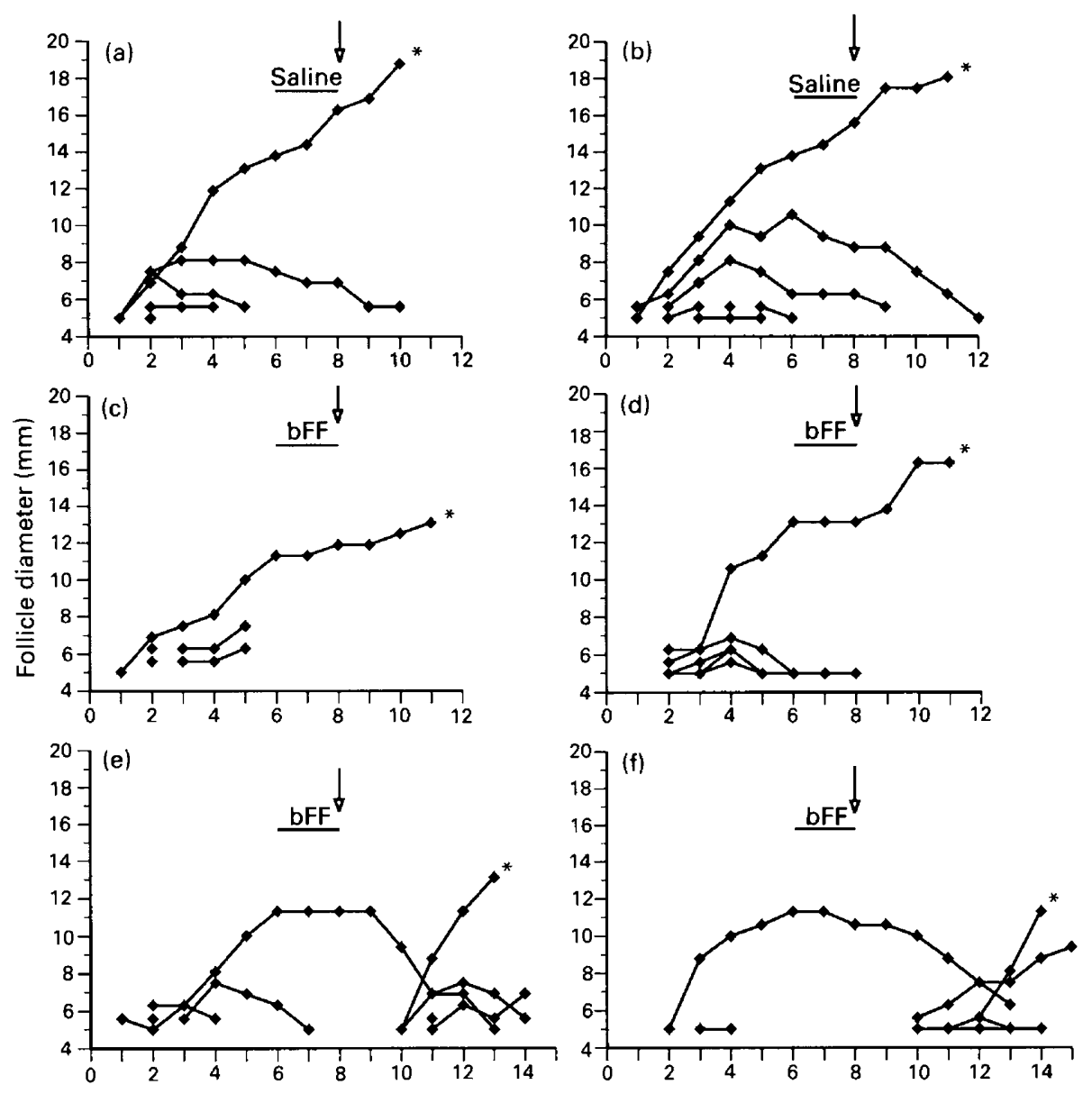

Day of oestrous cycle

Fig. 2. Patterns of growth and regression of individual follicles in representative heifers injected with saline or bovine follicular fluid (bFF) during the period indicated by horizontal bars. Arrows denote injection of $\mathrm{PGF}_{2 \alpha}$ on day 8 . Ovulatory follicles are indicated by asterisks. The dominant follicle of the first wave of follicular development ovulated in control heifers $(a, b)$ and in 5 of 10 bFF-treated heifers $(c, d)$. Regression of the first dominant follicle in five bFF-treated heifers was followed by the appearance of a second wave and ovulation of a dominant follicle selected from this wave $(e, f)$.

those in animals in which oestrus was delayed relative to controls, no differences were detected before, during or after the treatment period $(P>0.05)$.

Mean plasma concentrations of $\mathrm{LH}$ were not different between saline- and bFF-treated heifers before treatments, during the injection period, or during the $48 \mathrm{~h}$ after the end of treatments (data not shown). All animals exhibited a preovulatory surge of LH on the day of oestrus with one exception (discussed below).

Plasma progesterone profiles indicated that a functional corpus luteum was present in all heifers before $\mathrm{PGF}_{2 \alpha}$ injection, and that complete luteolysis occurred in all cases (Fig. 4a). Mean concentrations of progesterone were similar in bFF- and salinetreated heifers from day 5 to 10 of the oestrous cycle $(P>0.05)$.

Small increases in mean plasma concentrations of oestradiol were observed during the early luteal phase, and small peaks occurred on days 4 and 5 in control and bFF-treated heifers, respectively (Fig. 4b). After injection of $\mathrm{PGF}_{2 \alpha}$ on day 8, mean concentrations of oestradiol increased and reached maximal values on day 10 (the day of oestrus) in both control animals and in bFF-treated animals in which oestrus was not delayed. Concentrations of oestradiol in the bFF subgroup exhibiting delayed oestrus remained low until preovulatory increases were observed at about the time of the delayed oestrus (data not shown).

\section{Discussion}

Suppression of basal concentrations of plasma FSH was associated with an interruption of growth of the dominant follicle of the first wave in heifers. These results provide support for a critical role of FSH during development of dominant follicles, and suggest that, once selected, the dominant follicle requires normal plasma concentrations of FSH for continued growth and maintenance of functional dominance.

The longer interval between induction of luteolysis and oestrus in some bFF-treated animals in these experiments is similar to results of previous studies in which bFF was 
Table 2. Characteristics of the dominant follicle of the first wave of follicular development in heifers treated with saline (controls) or bovine follicular fluid (bFF) on days 6 and 7 and with PGF $_{2 a}$ on day 8 of the oestrous cycle

\begin{tabular}{|c|c|c|c|}
\hline $\begin{array}{l}\text { Characteristics } \\
\text { of dominant } \\
\text { follicle }\end{array}$ & $\begin{array}{c}\text { Controls } \\
(n=6)\end{array}$ & $\begin{array}{c}\text { bFF - oestrus } \\
\text { not delayed } \\
(n=5)\end{array}$ & $\begin{array}{c}\text { bFF - oestrus } \\
\text { delayed } \\
(n=5)\end{array}$ \\
\hline Day of appearance & $1.8 \pm 0.4^{\mathrm{a}}$ & $1.6 \pm 0.3^{\mathrm{a}}$ & $2.0 \pm 0.3^{\mathrm{a}}$ \\
\hline $\begin{array}{l}\text { Size on day } 5 \\
(\mathrm{~mm})^{*}\end{array}$ & $11.5 \pm 0.7^{\mathrm{a}}$ & $11.4 \pm 0.5^{\mathrm{a}}$ & $11.4 \pm 0.5^{\mathrm{a}}$ \\
\hline $\begin{array}{l}\text { Maximal size } \\
(\mathrm{mm})^{*}\end{array}$ & $16.7 \pm 0.7^{\mathrm{a}}$ & $15.9 \pm 0.7^{\mathrm{ab}}$ & $13.1 \pm 0.8^{b}$ \\
\hline $\begin{array}{l}\text { Day maximal size } \\
\text { reached }\end{array}$ & $10.5 \pm 0.3^{a}$ & $11.0 \pm 0.4^{a}$ & $7.2 \pm 1.0^{b}$ \\
\hline Persistence (days) & $9.7 \pm 0.7^{\mathrm{a}}$ & $10.6 \pm 0.5^{\mathrm{ab}}$ & $13.6 \pm 0.9^{b}$ \\
\hline $\begin{array}{l}\text { Growth rate } \\
\text { before treatment } \\
\left(\mathrm{mm} \mathrm{day}^{-1}\right)^{* *}\end{array}$ & $2.0 \pm 0.2^{\mathrm{a}}$ & $1.8 \pm 0.2^{\mathrm{a}}$ & $2.0 \pm 0.3^{\mathrm{a}}$ \\
\hline $\begin{array}{l}\text { Growth rate } \\
\text { during treatment } \\
\left(\mathrm{mm} \text { day }^{-1}\right)^{* * *}\end{array}$ & $0.9 \pm 0.2^{\mathrm{a}}$ & $0.2 \pm 0.1^{\mathrm{b}}$ & $-0.1 \pm 0.1^{b}$ \\
\hline
\end{tabular}

Values are means \pm SEM.

Means with no common superscripts within the same row differ significantly $(P<0.05)$.

*Diameter of antrum only.

${ }^{* *}$ Growth rate from day follicle first appeared until day 5 .

${ }^{* * *}$ Growth rate from day 6 to day 8 .

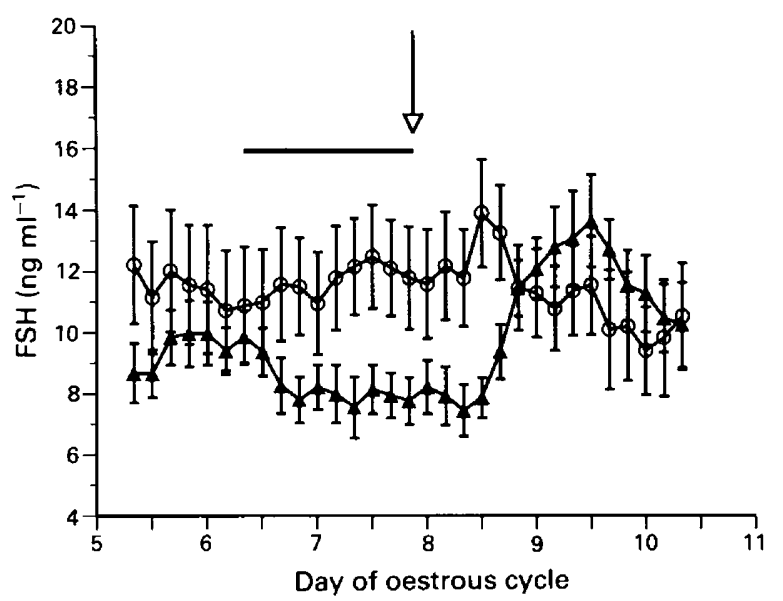

Fig. 3. Concentrations of FSH (means \pm SEM) in samples of plasma collected from heifers injected with saline $(n=6 ;-\mathrm{O}-)$ or bovine follicular fluid (bFF) $(n=10 ;-\boldsymbol{\Delta} \rightarrow$ ) every $12 \mathrm{~h}$ during the period indicated by the horizontal bar. The arrow denotes injection of $\mathrm{PGF}_{2 \alpha}$. Samples were collected at intervals of $4 \mathrm{~h}$. Data are shown for each treatment until the time when animals began to exhibit preovulatory gonadotrophin surges.

administered during the luteal phase prior to injection of $\mathrm{PGF}_{2 \alpha}$ (Johnson and Smith, 1985; Wallace and McNeilly, 1985, 1986). Ultrasonography revealed a direct relationship between the fate of the dominant follicle present at the start of treatments and
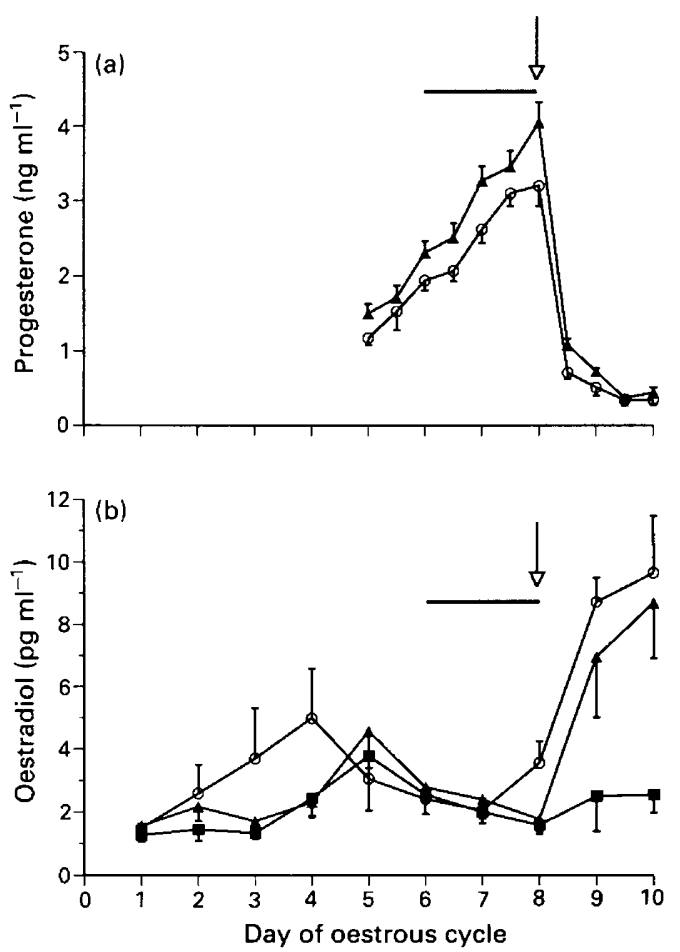

Fig. 4. Concentrations of (a) progesterone and (b) oestradiol in samples of plasma collected from heifers treated with saline $(n=6 ;-\mathrm{O}-$ ) or bovine follicular fluid (bFF) ( $n=10 ;-\mathbf{\Delta}-$ ) during the period indicated by horizontal bars. Injection of $\mathrm{PGF}_{2 \alpha}$ is shown by the arrows. In (b), concentrations of oestradiol in bFF-treated animals that exhibited oestrus at the same time as controls ( $\mathrm{bFF}-$ not delayed; $n=5 ;-\mathbf{\Delta} \longrightarrow$ ) are plotted separately from those in animals that took significantly longer than controls to exhibit oestrus (bFF - delayed; $n=5 ;-\square-$ ).

the time required for animals to exhibit oestrus. The occurrence of oestrus in control heifers 2 or 3 days after induction of luteolysis, followed by ovulation of the first dominant follicle, confirms previous reports demonstrating the ovulatory capacity of the dominant follicle of the first wave when $\mathrm{PGF}_{2 a}$ was administered during the growing phase of this follicle (Fortune et al., 1991), on day 7 of the oestrous cycle (Savio et al., 1990), or on day 8 of the oestrous cycle (Kastelic et al., 1990). The longer interval between $\mathrm{PGF}_{2 a}$ and oestrus in five of ten bFFtreated heifers compared with controls can be explained by regression of the dominant follicle of the first wave and the time required for recruitment of an entire new wave of follicular development. Associated with these events were significantly suppressed concentrations of FSH, which suggests that depriving the dominant follicle of normal basal concentrations of FSH on days 6 and 7 of the oestrous cycle can arrest growth, prevent further developmental changes, and cause a loss of functional dominance, i.e. the ability to suppress development of other follicles.

A surprising finding in this study was the pattern of follicular development in the five bFF-treated heifers that exhibited oestrus at the same time as controls. In a similar way to the dominant follicle of the bFF subgroup that displayed delayed oestrus, the dominant follicle in these heifers stopped growing during the period of suppressed FSH, suggesting that normal 
concentrations of FSH are important for growth of the dominant follicle at this stage in its development. The dominant follicles in this group resumed growth and ovulated following luteolysis, despite a similar degree of FSH suppression in these animals as in heifers displaying delayed oestrus. Resumption of growth following temporary follicular arrest has also been observed in women treated with a GnRH antagonist which caused a $50 \%$ decline in circulating gonadotrophin concentrations (Kettel et al., 1991). Taken together, these findings indicate that the developing dominant follicle is sensitive to changes in peripheral gonadotrophins, yet can in some cases reinitiate normal functions once gonadotrophin support is reinstated.

Because the dominant follicles in all 16 heifers in the study were of similar size before injections were initiated, response patterns cannot be explained by differences in size of the follicle at the time of treatment. One interpretation of these results is that days 6 and 7 may represent a transitional period during development of the dominant follicle of the first wave, when some follicles may be slightly more mature and thus less dependent on FSH support for continued functional dominance. It is possible that the dominant follicles in heifers not displaying delayed oestrus possessed greater sensitivity or responsivity to FSH and were thus capable of completing the final stages of preovulatory maturation. Picton and McNeilly (1991) showed that concentrations of FSH required to stimulate preovulatory follicular development vary markedly among ewes, suggesting that an individual threshold concentration of FSH exists for each animal. This idea is also supported by the observation of marked variations in endogenous concentrations of plasma FSH among ewes (Picton and McNeilly, 1991) and heifers (A. Turzillo, J. Baker and J. Fortune, unpublished observations) within the same breed. Alternatively, it is possible that the duration of decreased FSH concentrations in the present study was insufficient to elicit a completely uniform response in all ten animals injected with bFF.

The consistent suppressive effects of bFF on plasma FSH concentrations confirm previous reports demonstrating the selective influence of inhibin on FSH secretion in cattle (Ireland et al., 1983; Quirk and Fortune, 1986; Beard et al., 1989; Turzillo and Fortune, 1990). The period following bFF injections was characterized in these studies by a rebound in plasma FSH concentrations. In heifers in which the dominant follicle regressed after bFF treatment, the rebound in plasma FSH may have resulted in recruitment of the second follicular wave. We have shown that the secondary FSH surge that occurs about one day after the preovulatory gonadotrophin surges appears to play a role in recruitment of follicles for the first wave (Turzillo and Fortune, 1990), and Adams et al. (1992) have demonstrated an association between increases in plasma FSH and the emergence of follicular waves throughout the oestrous cycle in heifers.

There were no significant differences between control and bFF-treated heifers in mean concentrations of LH. However, one heifer in the bFF subgroup in which oestrus was not delayed failed to exhibit a preovulatory surge of LH. This animal exhibited a pattern of follicular characteristics similar to those in the other four heifers in this subgroup, but the dominant follicle of the first wave did not ovulate and became cystic. Although the reasons for the lack of an LH surge in this animal are unknown, they are presumed to be directly related to the ovulatory failure and may not be a direct result of bFF treatment since this heifer had normal preovulatory concentrations of plasma oestradiol.

Although the administration of bovine inhibin resulted in a consistent and significant suppression of concentrations of peripheral FSH in this study, it must be recognized that the crude preparation of inhibin used also contains numerous other non-steroidal factors (see Ireland, 1987 for review) and potential direct influences of these substances or inhibin itself on follicular growth cannot be clearly dissociated from the effects elicited by changes in plasma FSH. Direct inhibitory effects of ovine (Cahill et al., 1985; Campbell et al., 1991) and bovine (Larson et al., 1991) follicular fluid on growth of follicles in ewes have been reported. However, simultaneous administration of FSH and ovine (McNeilly et al., 1991) or bovine (McNatty et al., 1985; McNeilly, 1985) follicular fluid can prevent the negative effects of follicular fluid on ovarian activity in ewes, and bFF does not inhibit FSH-induced follicular development in prepubertal heifers (Moser et al., 1989a, b). Interpretation of these studies is further complicated by differences in the type of experimental model, dose and purity of FSH preparation, concentration of inhibin (relative to other components) and residual steroid content in follicular fluid used.

In summary, suppression of plasma FSH during the first wave of follicular development in heifers was associated with an interruption of growth of the dominant follicle. When luteolysis was induced at the end of treatment, the dominant follicle in some animals resumed growth and ovulated, but in others the dominant follicle regressed and the ovulatory follicle was selected from a newly recruited wave. These results provide evidence for an important role of FSH during follicular dominance in cattle, and suggest that growth of the dominant follicle of the first wave may require sustained concentrations of $\mathrm{FSH}$.

The assistance of J. Baker and R. Rodgers is gratefully acknowledged. The authors also thank D. J. Bolt of the USDA Animal Hormone Program, G. D. Niswender, W. Hansel and L. E. Reichert Jr for providing assay reagents. The cooperation of Taylor Packing Co, Wyalusing, PA was appreciated during collection of bFF. This study was supported by the USDA (CRCR-1-2125 and 90-37240-5715).

\section{References}

Adams GP, Matteri RL, Kastelic JP, Ko JCH and Ginther OJ (1992) Association between surges of follicle-stimulating hormone and the emergence of follicular waves in heifers Journal of Reproduction and Fertility 94 177-188

Baird DT (1987) A model for follicular selection and ovulation: lessons from superovulation Journal of Steroid Biochemistry 27 15-23

Beal WE, Milvae RA and Hansel W (1980) Oestrous cycle length and plasma progesterone concentrations following administration of prostaglandin F-2 $\alpha$ early in the bovine oestrous cycle Joumal of Reproduction and Fertility $\mathbf{5 9}$ 393-396

Beard AJ, Savva D, Glencross RG, McLeod BJ and Knight PG (1989) Treatment of ovariectomized heifers with bovine follicular fluid specifically suppresses pituitary levels of FSH- $\beta$ mRNA journal of Molecular Endocrinology 3 85-91

Bolt DJ and Rollins R (1983) Development and application of a radioimmunoassay for bovine follicle-stimulating hormone Joumal of Animal Science 56 146-154

Cahill LP, Driancourt MA, Chamley WA and Findlay JK (1985) Role of intrafollicular regulators and FSH in growth and development of large antral follicles in sheep Journal of Reproduction and Fertility 75 599-607

Campbell BK, Picton HM, Mann GE, McNeilly AS and Baird DT (1991) Effect of steroid- and inhibin-free ovine follicular fluid on ovarian follicles and ovarian hormone secretion Joumal of Reproduction and Fertility 93 81-96 
Driancourt MA, Fry RC, Clarke IJ and Cahill LP (1987) Follicular growth and regression during the 8 days after hypophysectomy in sheep Journal of Reproduction and Fertility $79635-641$

Dufour JJ, Cahill LP and Mauleon P (1979) Short- and long-term effects of hypophysectomy and unilateral ovariectomy on ovarian follicular populations in sheep Journal of Reproduction and Fertility 57 301-309

Fortune JE and Quirk SM (1988) Regulation of steroidogenesis in bovine preovulatory follicles Journal of Animal Science 66 (Supplement 2), 1-8

Fortune JE, Sirois J. Turzillo AM and Lavoir M (1991) Follicle selection in domestic ruminants Joumal of Reproduction and Fertility Supplement 43 $187-198$

Hillier SG (1991) Cellular basis of follicular endocrine function. In Ovarian Endocrinology pp 73-106 Ed. SG Hillier. Blackwell Scientific Publications, Cambridge

Ireland JJ (1987) Control of follicular growth and development Journal of Reproduction and Fertility Supplement 34 39-54

Ireland J] and Roche JF (1983) Development of nonovulatory antral follicles in heifers: changes in steroids in follicular fluid and receptors for gonadotropins Endocrinology 112 150-156

Ireland JJ, Curato AD and Wilson J (1983) Effect of charcoal-treated bovine follicular fluid on secretion of LH and FSH in ovariectomized heifers journal of Animal Science 57 1512-1516

Johnson SK and Smith MF (1985) Effects of charcoal-extracted, bovine follicular fluid on gonadotropin concentrations, the onset of estrus and luteal function in heifers Joumal of Animal Science 61 203-209

Kastelic JP, Knopf L and Ginther OJ (1990) Effect of day of prostaglandin F2 $\alpha$ treatment on selection and development of the ovulatory follicle in heifers Animal Reproduction Science 23 169-180

Kettel LM, Roseff SJ, Chiu TC, Bangah ML, Vale W, Rivier J, Burger HG and Yen SSC (1991) Follicular arrest during the midfollicular phase of the menstrual cycle: a gonadotropin-releasing hormone antagonist imposed follicularfollicular transition Journal of Clinical Endocrinology and Metabolism 73 $644-649$

Knopf L, Kastelic JP, Schallenberger E and Ginther OJ (1989) Ovarian follicular dynamics in heifers: test of two-wave hypothesis by ultrasonically monitoring individual follicles Domestic Animal Endocrinology 6 111-119

Larson GH, Mallory DS, Dailey RA and Lewis PE (1991) Gonadotropin concentrations, follicular development, and luteal function in pituitary stalktransected ewes treated with bovine follicular fluid Journal of Animal Science 69 4104-4111

Lentner M and Bishop T (1986) Experimental Design and Analysis. Valley Book Co., Blacksburg

Lussier JG and Carruthers TD (1989) Endocrine and superovulatory responses in heifers pretreated with FSH or bovine follicular fluid Theriogenology 31 779-794

McNatty KP, Hudson N, Gibb M, Ball K, Henderson KM, Heath DA, Lun S and Kieboom LE (1985) FSH influences follicle viability, oestradiol biosynthesis and ovulation rate in Romney ewes Journal of Reproduction and Ferility 75 121-131

McNeilly AS (1985) Effect of changes in FSH induced by bovine follicular fluid and FSH infusion in the preovulatory phase on subsequent ovulation rate and corpus luteum function in the ewe Joumal of Reproduction and Fertility $\mathbf{7 4}$ $661-668$

McNeilly AS, Jonassen JA and Fraser HM (1986) Suppression of follicular development after chronic LHRH immunoneutralization in the ewe Journal of Reproduction and Fertility $76481-490$
McNeilly AS, Crow W and Campbell BK (1991) Effect of follicular fluid and inhibin immunoneutralization on FSH-induced preovulatory follicle growth in the ewe Journal of Endocrinology $131401-409$

Moser MT, Garverick HA, Smith MF and Youngquist RS (1989a) Effect of bovine follicular fluid and follicle-stimulating hormone on follicular growth in unilaterally ovariectomized prepubertal heifers Journal of Dairy Science 72 2170-2178

Moser MT, Garverick HA, Smith MF and Youngquist RS (1989b) Follicular growth and endocrine patterns of prepubertal heifers administered bovine follicular fluid and (or) follicle stimulating hormone Animal Reproduction Science 18 227-242

Niswender GD, Reichert LE, Jr, Midgley AR, Jr and Nalbandov AR (1969) Radioimmunoassay for bovine and ovine luteinizing hormone Endocrinology 84 1166-1173

Picton HM and McNeilly AS (1991) Evidence to support a follicle-stimulating hormone threshold theory for follicle selection in ewes chronically treated with gonadotrophin-releasing hormone agonist Journal of Reproduction and Fertility 93 43-51

Quirk SM and Fortune JE (1986) Plasma concentrations of gonadotrophins, preovulatory follicular development and luteal function associated with bovine follicular fluid-induced delay of oestrus in heifers Journal of Reproduction and Fertility 76 609-621

Quirk SM, Hickey GJ and Fortune JE (1986) Growth and regression of ovarian follicles during the follicular phase of the oestrous cycle in heifers undergoing spontaneous and PGF-2 $\alpha$-induced luteolysis Joumal of Reproduction and Fertility 77 211-219

Richards JS (1980) Maturation of ovarian follicles: actions and interactions of pituitary and ovarian hormones on follicular cell differentiation Physiological Reviews $6051-89$

Robertson DM, Foulds LM, Leversha L, Morgan FJ, Hearn MTW, Burger HG, Wettenhall REH and deKretser DM (1985) Isolation of inhibin from bovine follicular fluid Biochemical and Biophysical Research Communications $126220-226$ SAS (1985) SAS User's Guide: Statistics. SAS Institute, Inc., Cary

Savio JD, Keenan L, Boland MP and Roche JF (1988) Pattern of growth of dominant follicles during the oestrous cycle of heifers Journal of Reproduction and Fertility $83663-671$

Savio JD, Boland MP, Hynes N, Mattiacci MR and Roche JF (1990) Will the first dominant follicle of the estrous cycle of heifers ovulate following luteolysis on day 7 Theriogenology $33677-687$

Sirois J and Fortune JE (1988) Ovarian follicular dynamics during the estrous cycle in heifers monitored by real-time uitrasonography Biology of Reproduction 39 308-317

Turzillo AM and Fortune JE (1990) Suppression of the secondary FSH surge with bovine follicular fluid is associated with delayed ovarian follicular development in heifers Joumal of Reproduction and Fertility 89 643-653

Turzillo AM and Fortune JE (1991) Fate of dominant ovarian follicles in heifers following suppression of plasma FSH Journal of Animal Science 69 (Supplement 1), 81, Abstract 602

Wallace JM and McNeilly AS (1985) Increase in ovulation rate after treatment of ewes with bovine follicular fluid in the luteal phase of the oestrous cycle Journal of Reproduction and Fertility 73 505-515

Wallace JM and McNeilly AS (1986) Changes in FSH and the pulsatile secretion of $\mathrm{LH}$ during treatment of ewes with bovine follicular fluid throughout the luteal phase of the oestrous cycle Joumal of Endocrinology 111 317-327

Zeleznik AJ and Hillier SG (1984) The role of gonadotropins in the selection of the preovulatory follicle Clinical Obstetrics and Gynecology 27 927-940 